\title{
Profiles of Pre-Service Primary Teachers: Attitudes, Self-Efficacy, and Gender Stereotypes in Teaching Science and Mathematics
}

\author{
Marianela Navarro ${ }^{{ }^{*}}$ (D), Annjeanette Martin ${ }^{1}$ (D), María P. Gómez-Arízaga ${ }^{1}$ (D) \\ 1 Universidad de los Andes, CHILE
}

Received 10 October $2021 \cdot$ Accepted 16 December 2021

\begin{abstract}
This descriptive study aims to analyze personality traits associated with gender and attitudes and self-efficacy towards teaching science and mathematics in pre-service primary teachers. Convenience sampling was used to select 92 pre-service primary teachers in Chile, who were administered a set of instruments to measure these variables; these instruments have displayed adequate levels of validity and reliability. Results show that an important percentage of pre-service primary teachers have low levels of self-efficacy and attitudes toward teaching these subjects and have personality traits that indicate marked gender stereotypes. Furthermore, the measured variables together generate distinct profiles of pre-service primary teachers. The implications of these results are discussed in relation to creating more equitable school environments that strive to attract more students, especially girls, to engage in science and mathematics.
\end{abstract}

Keywords: attitudes, gender stereotypes, math instruction, pre-service primary teachers, science instruction, self-efficacy

\section{INTRODUCTION}

In Chile, important gender gaps in learning outcomes in math and science tend to be unfavorable for women (Organisation for Economic Co-operation and Development [OECD], 2016). Although there have been some improvements, these differences are substantial and tend to increase along the schooling trajectory (Agencia de la Calidad de la Educación, 2018). Beginning in elementary school, girls progressively distance themselves from math and science for multiple reasons that can be grouped into four dimensions: student, family and peers, school, and society (United Nations Educational Scientific and Cultural Organization [UNESCO], 2019).

Within the school dimension, primary teachers play a fundamental role given that they are the first representatives of the scientific community with whom children have contact (Michaluk et al., 2018). Teachers have been found to have an impact on student learning (Riegle-Crumb et al., 2015), on their attitudes toward science (Korur et al., 2016) and math (Michaluk et al., 2018; Ren et al., 2016), on their self-efficacy in these subjects (Gurin et al., 2017), on their gender stereotypes (Thomas, 2017), and on their future decisions to undertake scientific careers (Cvencek et al., 2011; Dejarnette, 2012; Nadelson et al., 2013).

In this context, both research and educational policies have paid increasing attention to primary teachers (Riegle-Crumb et al., 2015). The focus for improving primary instruction has long centered on teachers' disciplinary mastery. This is because primary teachers are prepared as generalists--in Chile they are prepared in four subjects: natural sciences, mathematics, language arts, and history, geography, and social sciences (Ministerio de Educación, [Mineduc], 2012). As a consequence, primary teachers have less disciplinary knowledge than secondary teachers. This seems to be particularly accentuated in mathematics (Varas et al., 2018) and in science (Riegle-Crumb et al., 2015).

Content knowledge, however, is necessary but insufficient in preparing highly-qualified teachers. In this sense, it is essential to consider that pre-service teachers come with a set of conceptualizations, attitudes, and emotions about the teaching and learning of different subjects (including science and math) that are the result of their own experience as students in school (Blalock et al., 2008; Brígido et al., 2013; Dejarnette, 2012; Korur et al., 2016; Nadelson et al., 2013; Verdugo et al., 2017).

(c) 2022 by the authors; licensee Modestum. This article is an open access article distributed under the terms and conditions of the Creative Commons Attribution License (http://creativecommons.org/licenses/by/4.0/).

$\square$ mnavarroc@uandes.cl (*Correspondence) $\square$ amartin@uandes.cl $\$ mpgomez@uandes.cl 


\section{Contribution to the literature}

- The article shows that an important percentage of pre-service primary teachers have marked gender stereotypes and unfavorable attitudes and low self-efficacy for teaching science and mathematics.

- The article shows a positive and statistically significant correlation between attitudes toward teaching science and mathematics and self-efficacy in the teaching of these subjects in pre-service primary teachers.

- The article shows that gender stereotypes combine with socio-affective variables associated with the teaching of science and mathematics, generating different profiles in pre-service primary teachers.

Therefore, teachers' negative socio-affective dispositions (negative predispositions or attitudes, anxiety, low self-efficacy, etc.) towards science and/or mathematics are transferred to students (Legañoa et al., 2017). These negative dispositions seem to have a great impact, particularly on girls' beliefs about who is good at science and mathematics based on gender (Beilock et al., 2010; Finlayson, 2014; Gurin et al., 2017; Lewis, 2015). Similarly, it has been observed that teachers with a negative predisposition toward teaching science and mathematics are perceived by students as hostile and indifferent and students remember having been humiliated by them in front of their classmates. Particularly, girls remember having been ridiculed with greater frequency than boys; girls also remember having received less formative feedback from teachers (Van der Sandt \& O'Brien, 2017).

Given that the majority (78\%) of primary teachers in Chile are women (Mineduc, 2017) they are likely to have faced some of these previously described situations in their own schooling experience; they might, therefore, be more prone to have developed negative feelings about these subjects (Beilock et al., 2010; Legañoa et al., 2017; Lewis, 2015; Oppermann et al., 2019; Ren et al., 2016). Furthermore, teachers also model commonplace gender stereotypes to their female students, displaying unfavorable attitudes towards mathematics (Beilock et al., 2010) and science (Camacho, 2018).

In short, to achieve greater gender equality in the teaching and learning of science and mathematics and for the future professional choices of girls (Mizala et al., 2015), it is of utmost importance to improve primary teacher education, moving beyond disciplinary mastery and addressing these socio-affective variables.

\section{Teacher Variables Related to the Gender Gap in Science and Mathematics}

As a framework for the aforementioned socioaffective dispositions of pre-service teachers, Bandura's social-cognitive theory has been adopted, which proposes a central and critical role of social and affective variables in the learning process (Bandura, 2001). Socioaffective variables have been related to attitudes, emotions, and feelings, and include constructs such as motivation, self-efficacy, self-image, among others (Zhu \& Zhou, 2012). These constructs have been found to have equal importance for learning as well as cognition (Stern, 1983).

\section{Attitudes toward teaching science and mathematics}

According to Moscovici (1985), attitudes are an organization of beliefs (prejudices, tendencies, feelings, fears, ideas, and convictions) about an object that predispose how a person acts in relation to this object. In this context, attitudes toward teaching science and mathematics could be understood as a teacher's or preservice teacher's predisposition to react favorably or unfavorably toward the teaching of these subjects.

Attitudes toward teaching science and mathematics are important to consider in primary teacher education given their impact on students (Kazempour, 2014; Korur et al., 2016; Ren et al., 2016; Riegle-Crumb et al., 2015; Wendt \& Rockinson-Szapkiw, 2018). Teachers' attitudes toward science and mathematics, combined with their teaching practices, have a strong influence on student achievement, students' attitudes toward these subjects, scientific literacy, and on student interest in pursuing STEM careers (Kazempour, 2014; Wendt \& RockinsonSzapkiw, 2018; Wilkins, 2010).

Korur et al. (2016) found that primary teachers who displayed positive attitudes toward teaching science are more likely to promote positive attitudes toward learning science in their students. On the contrary, primary teachers who displayed negative attitudes toward teaching science, dedicated less time to scientific topics and their classes were more lecture-like.

Furthermore, attitudes of pre-service teachers are heavily influenced by their past schooling experiences, learning science and mathematics themselves (Nelson, 2015). Unfavorable experiences in these subjects lead to teachers who have negative attitudes, a lack of confidence, lack of knowledge, and a dislike of science and mathematics; these teachers then generate these same feelings in their students (Legañoa et al., 2017). Furthermore, due to their lack of confidence, their teaching practices are more teacher-centered than student-centered (Ren et al., 2016).

Hence, there is a great need to examine attitudes toward the teaching of these subjects early in initial teacher education (Blalock et al., 2008; Saad \& Boujaoude, 2012). Thus, teacher education programs could consider providing formative instances that aim to 
improve pre-service teachers' predispositions toward teaching science and mathematics. These decisions, in the medium term, could, in turn, improve student attitudes at school (Michaluk et al., 2018; Yeigh et al., 2016).

\section{Self-efficacy in the teaching of science and mathematics}

According to Bandura (1977a), self-efficacy is a complex, socially-constructed concept that consists of two dimensions: the expectation of results and personal efficacy. The expectation of results refers to the belief that one's behavior will produce desired results, whereas, personal efficacy is the confidence in executing actions that will lead to the achievement of one's desired goals. Hence, self-efficacy for teaching science and mathematics can be understood as the belief and selfconfidence that pre-service teachers have that they will be able to execute pedagogical actions that will lead to effective student learning in these subjects.

Exploring self-efficacy in the teaching of science and mathematics in pre-service primary teachers is relevant given that there are critical links to their professional performance; it is even considered a predictor of performance (Bandura, 1997b). For example, teachers with higher self-efficacy tend to adopt a constructivist learning approach, evidenced in student-centered practices, greater willingness to change teaching methods, greater persistence when confronting difficult situations, and a lower likelihood of criticizing students (Chan \& Lay, 2021; Menon \& Sadler, 2016; Verdugo et al., 2017). Furthermore, teachers with higher self-efficacy firmly believe that student achievement is influenced by effective teaching and they have confidence in their own capacity to impact student learning in science (Gencer \& Cakiroglu, 2007) and mathematics (Peker et al., 2018). All of this leads to a positive impact in student learning (Menon \& Sadler, 2016).

On the contrary, low self-efficacy in teaching leads to teachers who consider lecture-style lessons and theoretical teaching strategies more appropriate (Mateos-Núñez et al., 2020). These teachers avoid exploratory activities (Menon \& Sadler, 2016), heavily depend on teaching resources like text books and kits (Haney et al., 2002; Van Aalderen-Smeets et al., 2012), and limit the thinking and creativity of their students (Chan \& Lay, 2021). Similarly, low teacher self-efficacy is related to professional burnout and an increase in stress levels (Brígido et al., 2013).

Regarding self-efficacy in the teaching of mathematics, at least $60 \%$ of pre-service primary teachers doubt their teaching potential (Verdugo et al., 2017). This is consistent with findings by Nelson (2015) who looked at mathematics self-efficacy in pre-service teachers who believed that they would be effective classroom teachers, but only after a long time and great effort.
With respect to self-efficacy in the teaching of science, studies have shown that pre-service primary teachers feel better prepared to teach life and earth sciences than to teach chemistry, physics, and engineering, and tend to avoid teaching the latter (Banilower et al., 2013; Brígido et al., 2013; Mateos-Núñez et al., 2020).

Similar to what occurs with attitudes, the school experiences of pre-service teachers have an impact on their self-efficacy for teaching mathematics (Nelson, 2015) and science (Menon \& Sadler, 2016). For example, in Nelson's (2015) study, teachers with lower selfefficacy indicated that they had had negative experiences during their primary school years. In effect, attitudes and self-efficacy for the teaching of science and mathematics have been found to be tightly related (Bursal, 2010; Korur, et al., 2016; Menon \& Sadler, 2016).

However, low self-efficacy or unfavorable attitudes toward teaching mathematics and/or science does not necessarily discourage young people from becoming primary teachers (Gurin et al., 2017). Yet, this perception of low ability is part of a cycle that transmits negative emotions about science and/or mathematics (Beilock et al., 2010; Lewis, 2015). Given that most primary teachers are women, their negative attitudes toward mathematics are more likely to have an influence on girls than on boys (Ren et al., 2016). Furthermore, the stereotype that "boys are good at math and girls at reading" is more commonly perpetuated in these classrooms, along with beliefs that girls will not be successful in mathematics courses (Beilock et al., 2010).

\section{Future teachers' gender stereotypes in STEM areas}

Beliefs and gender stereotypes are among the variables that influence the gender gap in science and mathematics (Del Río et al., 2013; Dunkake \& Schuchart, 2015; Mizala et al., 2015; Shepherd, 2016; Thomas, 2017). Gender stereotypes are strong cultural patterns that define different goals and expectations for men and women. These beliefs create the perception that certain disciplines or careers, for example STEM areas, are more or less compatible for one gender or the other. These beliefs are also held by teachers, and suggest that men may have a natural disposition for mathematics (Spelke, 2005) and the sciences (Reuben et al., 2014), while women may have innate abilities for language (Hinnant et al., 2009).

These stereotypes are also manifested in how teachers' explain performance in mathematics based on gender: boys' achievement is attributed to natural abilities, while girls' achievement is explained by effort. On the contrary, failure for boys is attributed to lack of effort, while for girls it is attributed to lack of ability (Espinoza et al., 2014). Other studies, for example Espinoza and Taut (2016), have found that teachers interacted less with girls and that these interactions were less cognitively challenging. Hence, gender stereotypes 
are part of a hidden curriculum, transmitting biases through teaching resources, methodologies, and classroom interactions (UNESCO, 2019).

Furthermore, the more entrenched the gender stereotype in the teacher, the more ingrained the biases are in their students (Keller, 2007). These stereotypes are instilled as early as 5 th grade in girls, despite the fact that their performance is similar to that of boys (Banjong, 2014). Even more worrisome is that these biased expectations can affect self-esteem and self-efficacy in girls, limiting their possibilities and achievements; at the same time, they continue to reinforce social inequalities (Arias, 2016; UNESCO, 2019). One study in Chile examined the achievement expectations of pre-service teachers regarding their students and found that these expectations contained gender biases, with lower achievement expectations for girls. This indicates a need to confront these beliefs in initial teacher education (Mizala et al., 2015).

Delving into understanding these beliefs could help teachers develop a more balanced vision regarding the learning potential of boys and girls. Lower female participation in science and mathematics could be due, in part, to these sub-conscious stereotyped messages that girls and boys inherit from their teachers (Del Río et al., 2013; de Kraker-Pauw et al., 2016).

\section{Research Problem}

The revised literature demonstrates the impact that attitudes and self-efficacy of pre-service primary teachers toward teaching science and mathematics can have on student learning. However, these factors have often not been considered in research conducted in Chile by institutions that prepare the country's primary teachers. Furthermore, no studies have been found in Chile that examine the relationship between these socioaffective characteristics of pre-service teachers and their gender biases. Such a study could help to explain the gender gap in science and mathematics, especially considering that these variables are influenced by culture, common background, geographical location, religion, language, and social class (Brígido et al., 2013; Jones \& Leagon, 2014).

Based on the presented information, the purpose of this study is to analyze the attitudes and self-efficacy related to the teaching of science and mathematics and gender stereotypes of pre-service primary teachers. This objective can be divided into the following research questions:

1. What are the gender stereotypes and attitudes and self-efficacy toward teaching science and mathematics of pre-service primary teachers?

2. What is the relationship between attitudes and selfefficacy toward teaching science and mathematics and gender stereotypes of pre-service primary teachers?
3. What profiles can be established combining the gender stereotypes, attitudes and self-efficacy toward teaching science and mathematics in pre-service primary teachers?

This study aims to improve pre-service primary teacher education in Chile, specifically making visible socio-affective factors and gender biases associated with science and mathematics. It is suggested that primary teacher preparation programs consider including these factors as part of their training. This could lead to the creation of more equitable school environments that would permit maximum development in both girls and boys and work toward increasing the participation of women in science and mathematics.

\section{METHODS}

\section{Type of Study}

A descriptive research design was chosen given the objectives of the study and the research questions Specifically, the aim is to characterize gender stereotypes, and attitudes and self-efficacy related to teaching science and mathematics in pre-service primary teachers and how these variables are related. An additional aim seeks to describe different profiles of preservice primary teachers, combining the variables under examination.

\section{Participants}

Using convenience sampling, 92 pre-service teachers were selected from a 4-year primary teacher education program at a private university in Chile's SantiagoMetropolitan Region. In this sample, 90 participants were female $(97,8 \%)$ and two were male $(2,2 \%)$. Although the number of women in the sample is overrepresented in relation to the percentage of female primary teachers at the national level $(78 \%)$, the observed percentage $(98 \%)$ is consistent with the percentage of women who have studied primary education for the last 10 years in the university where the study was conducted (98\%). Additionally, of the 92 participants, $40(43,5 \%)$ of them were in the second year of their program, whereas $52(56,5 \%)$ of them were in their third year. These cohorts were selected to control for possible effects that the courses in the program related to teaching science and mathematics might have; these two cohorts had not yet taken these courses at the time of data collection. Table 1 shows the participants.

Table 1. Participants by year in the program and sex

\begin{tabular}{crrrr}
\hline & & \multicolumn{2}{c}{ Sex of participant } & \multirow{2}{*}{ Total } \\
\cline { 2 - 3 } & Women & Men & \\
\hline Year of their & Second & $39(42.4 \%)$ & $1(1.1 \%)$ & $40(43.5 \%)$ \\
primary teacher & Third & $51(55.4 \%)$ & $1(1.1 \%)$ & $52(56.5 \%)$ \\
education program & Thin & & \\
Total & $90(97.8 \%)$ & $2(2.2 \%)$ & $92(100 \%)$ \\
\hline
\end{tabular}




\section{Instruments}

\section{Scale for measuring attitudes toward science and mathematics teaching}

To measure participants' attitudes toward the teaching of science, the instrument Dimensions of Attitude toward Science (DAS) created by van AalderenSmeets and van der Molen (2013) was used, which was designed for pre-service teachers in preparation programs and in-service teachers already working in the field. This instrument has 28 5-point Likert-type items that range from "completely disagree" (1) to "completely agree" (5). The DAS instrument has been translated to Spanish (see Korur et al., 2016) and has been used with pre-service elementary teachers. The DAS has been found to have adequate reliability (Cronbach's alpha=.82) and construct validity (RMSEA<.08) (Korur et al., 2016; van Aalderen-Smeets \& van der Molen, 2013). Given that there were no available instruments in Spanish to measure the attitudes towards mathematics teaching, an adaptation of the DAS was created; this adaptation consisted of substituting the term science for mathematics, and analyzing the appropriateness of the modification of each item by the research team.

\section{Self-efficacy scale for the teaching of science and mathematics}

To measure self-efficacy in the teaching of science and mathematics, the Mathematics Teaching Efficacy Belief Instrument (MTEBI) was used, adapted to Spanish, called ECEEM, for its initials in Spanish. It has been validated in Chile and has displayed good construct validity and reliability indexes (RMSEA=.06) (Cronbach's alpha>.81), and therefore constitutes an adequate instrument to measure efficacy beliefs in teaching mathematics in preservice primary teachers (Verdugo et al., 2017). The Chilean version of the instrument has 21 five-point Likert-type items, that range from completely disagree (1) to completely agree (5). Given that there were no available instruments in Spanish to measure self-efficacy in the teaching of science, the ECEEM was adapted, substituting the term science for mathematics. Each item was carefully examined by the research team, judging the appropriateness of the adaptation for each item.

\section{Instrument to measure gender-related personality characteristics}

To measure personality traits associated with gender the Inventario Masculino-Femenino (IMAFE), of Mexican origin (Lara, 1993) was used, which measures the internalization of the gender stereotypes that are present in Latinamerican cultures. The IMAFE has 60 items, each item presents an adjective, which the participant responds to on a 7-point Likert scale that includes (1) I am never or almost never like this to (7); I am always like this. There are 60 items distributed over four scales, two of which are considered positive (masculinity and femininity) and two are negative (machismo and submission). Masculinity is defined as positive traits that can be attributed to men (Lara, 1993), related to pragmatism and an orientation to action. This subscale has adjectives that are considered masculine and positive, such as: "confidence in oneself", "analytical", "self-sufficient". Machismo, on the other side, contemplates attributes that are evaluated as masculine and negative, related to aggression, domination and stubbornness. This subscale includes characteristics such as "authoritarian", "arrogant", and "aggressive". Femininity is defined as positive traits that characterize women (Lara, 1993) and is related to good interpersonal skills, concern for others and expressivity. Femininity includes characteristics such as "caring," "understanding," and "benevolent." Finally, submission contemplates traits that are considered feminine and negative, associated with abnegation, dependence, subordination, and weakness. Some examples of these adjectives are "insecure," "shy," and "easilyinfluenced." The instrument has adequate levels of reliability (Cronbach's alpha between .78 and .88 for the subscales) and construct validity (Martínez-Gómez et al., 2012).

\section{Data Analysis}

The analyses presented will be organized according to the research questions.

1. To respond to the question: What are the gender stereotypes and attitudes and self-efficacy toward teaching science and mathematics of pre-service primary teachers?, descriptive statistical analyses were conducted, considering the mean and the standard deviation. Similarly, to account for variation, each measure was transformed into a categorical variable. To this effect, the raw score was transformed into a Z-score and using the average as a contrast reference, levels were defined. Five levels of these variables were defined using the cut-offs defined by Cohen (1992): Much lower than the mean $(\leq-0.8)$, lower than the mean $(>-0.8 y<-0.5)$, similar to the mean $(\geq-0.5 ; y \leq 0.5)$, higher than the mean $(>0.5 ; y<0.8)$, and much higher than the mean $(\geq 0.8)$.

2. To examine: What is the relationship between attitudes and self-efficacy toward teaching science and mathematics and gender stereotypes of pre-service primary teachers?, a Pearson's correlation coefficient was conducted, using raw scores of the analyzed variables.

3. To answer the research question: What profiles can be established combining the gender stereotypes, attitudes and self-efficacy toward teaching science and mathematics in pre-service primary teachers?, a hierarchical cluster analysis was conducted. Cluster analysis is a multivariate exploratory technique with the purpose of grouping cases in larger groups with high 
Table 2. Descriptive statistics of variables measured

\begin{tabular}{|c|c|c|c|c|c|c|c|c|}
\hline \multirow[b]{2}{*}{ Variables analyzed } & \multirow[b]{2}{*}{$\mathrm{N}$} & \multirow[b]{2}{*}{ M } & \multirow[b]{2}{*}{$\mathrm{SD}$} & \multicolumn{5}{|c|}{ Level compared to the mean } \\
\hline & & & & $\begin{array}{l}\text { Much lower } \\
\text { than the mean }\end{array}$ & $\begin{array}{c}\text { Lower than } \\
\text { the mean }\end{array}$ & $\begin{array}{l}\text { Similar to the } \\
\text { mean }\end{array}$ & $\begin{array}{c}\text { Higher than } \\
\text { the mean }\end{array}$ & $\begin{array}{l}\text { Much higher } \\
\text { than the mean }\end{array}$ \\
\hline Attitude toward teaching science & 87 & 3.73 & 0.58 & $16(18.4 \%)$ & $8(9.2 \%)$ & $39(44.8 \%)$ & $7(8.0 \%)$ & $17(19.5 \%)$ \\
\hline $\begin{array}{l}\text { Attitude toward teaching } \\
\text { mathematics }\end{array}$ & 91 & 3.74 & 0.71 & $17(18.7 \%)$ & $8(8.8 \%)$ & $37(40.7 \%)$ & $11(12.1 \%)$ & $18(19.8 \%)$ \\
\hline Self-efficacy for teaching science & 92 & 3.84 & 0.46 & $20(21.7 \%)$ & $9(9.8 \%)$ & $42(45.7 \%)$ & $3(3.3 \%)$ & $18(19.6 \%)$ \\
\hline $\begin{array}{l}\text { Self-efficacy for teaching } \\
\text { mathematics }\end{array}$ & 87 & 3.87 & 0.48 & $18(20.7 \%)$ & $8(9.2 \%)$ & $33(37.9 \%)$ & $8(9.2 \%)$ & $20(23.0 \%)$ \\
\hline Femininity & 88 & 5.70 & 0.75 & $18(20.5 \%)$ & $10(11.4 \%)$ & $35(39.8 \%)$ & $7(8.0 \%)$ & $18(20.5 \%)$ \\
\hline Masculinity & 88 & 4.85 & 0.71 & $20(22.7 \%)$ & $12(13.6 \%)$ & $22(25.0 \%)$ & $16(18.2 \%)$ & $18(20.5 \%)$ \\
\hline Submission & 88 & 3.24 & 0.76 & $19(21.6 \%)$ & $7(8.0 \%)$ & $38(43.2 \%)$ & $6(6.8 \%)$ & $18(20.5 \%)$ \\
\hline Machismo & 88 & 3.36 & 0.98 & $15(17.1 \%)$ & $13(14.8 \%)$ & $42(47.7 \%)$ & $7(8.0 \%)$ & $11(12.5 \%)$ \\
\hline
\end{tabular}

degrees of internal homogeneity (intra-cluster) and external heterogeneity (inter-clusters) (Battaglia et al., 2017; Hair et al., 1999). As a grouping method, Ward's method was used and to define the number of conglomerates, the dendrogram graphic was examined, which represents how the hierarchical classification among individuals is formed. Given that the cluster analysis is not an inferential statistics technique, assumptions of normality and homoscedasticity have little importance; however, to conduct this kind of test, all variables must be in the same units (Battaglia et al., 2017). Hence, previous to the cluster analysis, the eight variables were transformed into Z-scores, given that not all of them use the same scale.

All analyses were performed with SPSS version 25.

\section{Ethical considerations}

The pre-service primary education student participation was voluntary and they signed an informed consent letter. Additionally, this research project was submitted for review and approved by the ethics committee of the affiliated research institution.

\section{RESULTS}

Table 2 presents the results of the descriptive analysis, indicating the means and standard deviations of each of the eight variables measured. Both the attitudes and the self-efficacy related to teaching science and mathematics show a positive tendency, with values higher than 3 (median of the 1 to 5 scale used to measure these variables). Regarding the personality characteristics associated with gender, the characteristics considered positive (femininity and masculinity), on average, presented values higher than 4 (which is the median of the 1 to 7 scale used for this instrument). On the other hand, the characteristics considered negative (submission and machismo), presented values lower than 4 . Going beyond the average score, the classification by level shows the variation observed in each variable. Hence, it is possible to see that there are pre-service teachers with scores substantially far from the mean; most remarkable being the percentage of pre-service teachers whose attitudes and self-efficacy related to teaching science and mathematics are lower or much lower than average. Furthermore, in the personality dimensions associated with gender, there is a relevant proportion of students with low levels of femininity and masculinity and high levels of submission and machismo.

Table 3 displays the correlation results between all of the measured variables. There were statistically significant positive correlations of different magnitudes: there were significant high positive correlations ( $>.60$ to 1 ) between attitudes toward teaching mathematics and self-efficacy for teaching the same subject. There were significant moderate positive correlations (>.40 to $\leq .60)$ between self-efficacy towards teaching mathematics and self-efficacy towards teaching science; between selfefficacy towards teaching mathematics and attitudes towards teaching science; between attitudes towards teaching science and attitudes towards teaching mathematics. There was moderate negative $(>.25$ to $\leq .40)$ correlations between submission and masculinity.

Figure 1 presents three profiles of pre-service primary teachers after combining the variables measured: attitudes toward teaching science and mathematics, self-efficacy toward teaching science and mathematics, and gender-related personality traits (femininity, masculinity, machismo, and submission). Profile 1 is characterized by high masculinity and low submission, this translates into being competitive, decisive, self-confident, a good leader, and unpersuadable. Profile 2 displays low levels of masculinity, high levels of submission, and low attitudes and self-efficacy toward teaching science and mathematics. A few characteristics of this profile are insecure, indecisive, passive, conformist, nervous when teaching science or mathematics, and the belief that science and mathematics are difficult. Finally, profile 3 shows high levels of femininity and high attitudes and self-efficacy related to teaching science and mathematics. Participants with this profile, for example, reported being generous, understanding, and cooperative. They also think that science and mathematics should be taught as early as possible; they 
Table 3. Correlations between variables measured

\begin{tabular}{|c|c|c|c|c|c|c|c|c|}
\hline & $\begin{array}{c}\text { Attitudes } \\
\text { teaching } \\
\text { science }\end{array}$ & $\begin{array}{c}\text { Attitudes } \\
\text { teaching } \\
\text { math }\end{array}$ & $\begin{array}{c}\text { Self-efficacy } \\
\text { teaching } \\
\text { science } \\
\end{array}$ & $\begin{array}{l}\text { Self-efficacy } \\
\text { teaching math }\end{array}$ & Femeninity & Masculinity & Machismo & Submission \\
\hline $\begin{array}{l}\text { Attitudes teaching } \\
\text { science }\end{array}$ & 1 & $.409^{* *}$ & $.640^{* *}$ & $.463^{* \star}$ & $.234^{*}$ & .176 & -.146 & -.099 \\
\hline $\begin{array}{l}\text { Attitudes teaching } \\
\text { math }\end{array}$ & & 1 & $.301^{* *}$ & $.694^{* *}$ & .157 & .106 & -.176 & -.037 \\
\hline $\begin{array}{l}\text { Self-efficacy } \\
\text { teaching science }\end{array}$ & & & 1 & $.527^{\star \star}$ & $.319^{* *}$ & .155 & -.151 & -.051 \\
\hline $\begin{array}{l}\text { Self-efficacy } \\
\text { teaching math }\end{array}$ & & & & 1 & $.307^{\star *}$ & .127 & -.144 & -.131 \\
\hline Femininity & & & & & 1 & .078 & $-.246^{*}$ & .157 \\
\hline Masculinity & & & & & & 1 & .118 & $-.399^{* *}$ \\
\hline Machismo & & & & & & & 1 & .022 \\
\hline Submission & & & & & & & & 1 \\
\hline
\end{tabular}

* Correlation is significant at the 0.05 level; ${ }^{* *}$ Correlation is significant at the 0.01 level

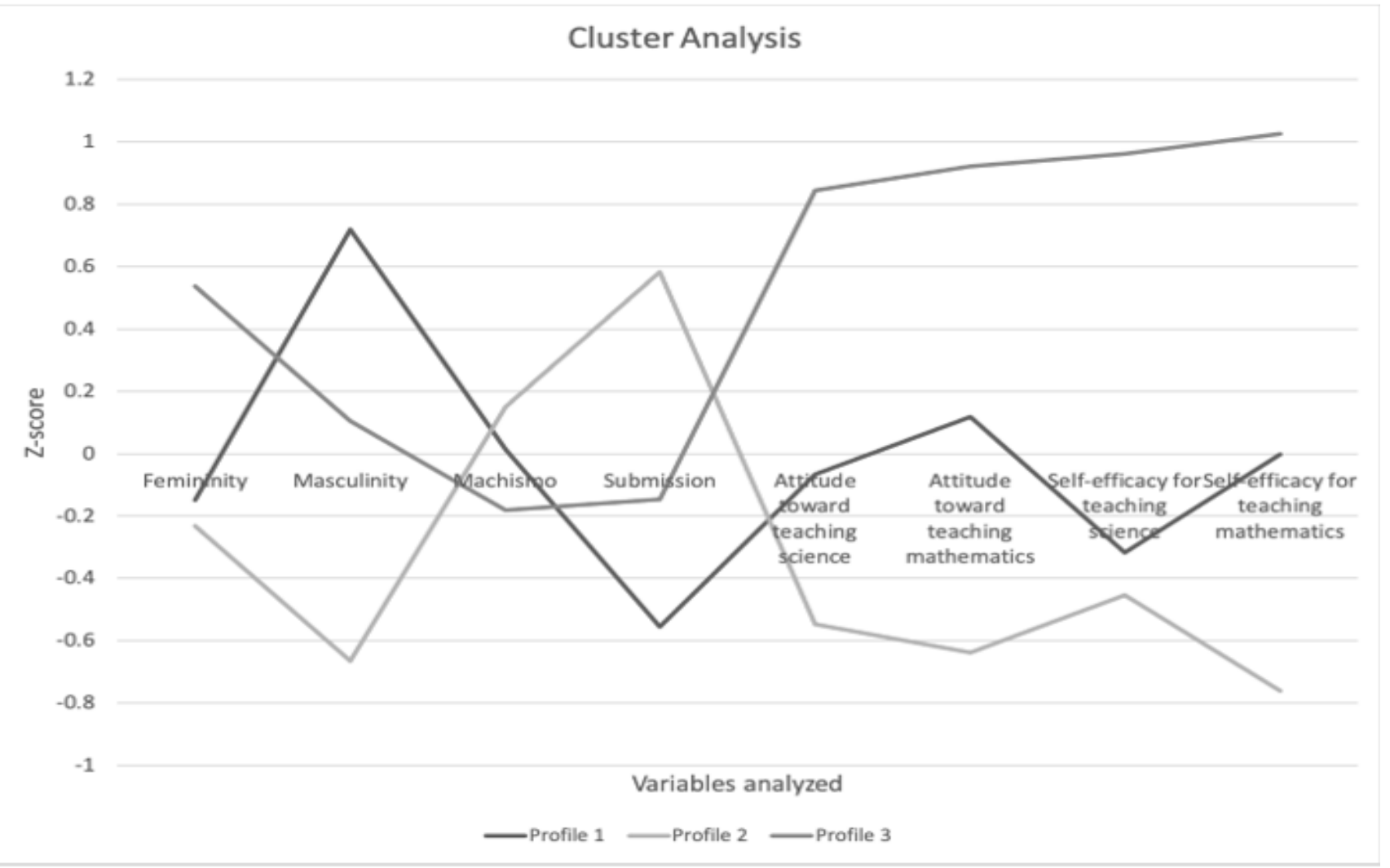

Figure 1. Profiles of pre-service primary teachers after combining the variables measured

feel happy when teaching these subjects; they think they can successfully solve math problems; and they declare that they will search for better strategies to respond to student doubts.

To understand the profiles in more depth, in Table 4 there is a characterization of each one according to the items with the highest and lowest scores obtained on the variables identified as relevant for each profile.

\section{DISCUSSION AND CONCLUSIONS}

In general terms, the findings are in line with previous research in which similar socio affective variables in pre-service and in-service teachers have been measured. Regarding self-efficacy and attitudes towards teaching, it has been found that many preservice teachers display positive results and tend to be positive about their confidence in teaching science and mathematics. However, similar to the present findings, there is an important group that doubts their capacities to produce meaningful learning in their students (Kazempour, 2014; Verdugo et al., 2017).

Regarding the research question: what are the gender stereotypes and attitudes and self-efficacy toward teaching science and mathematics of pre-service primary teachers? It was found that, in general terms, both the 
Table 4. Characterization of profiles based on lowest and highest scoring items in the measured variables

\begin{tabular}{lll}
\hline \multirow{3}{*}{ Masculinity } & Profile 1 & Profile 2 \\
& $\checkmark$ Competitive & Low scores on: \\
& $\checkmark$ I make decisions easily & $\checkmark$ Skilled in leading \\
& $\checkmark$ Sure of myself & $\checkmark$ Analytical \\
& $\checkmark$ Skilled in leading & $\checkmark$ Rational \\
Submission & Low scores on: & High scores on: \\
& $\checkmark$ Weak personality & $\checkmark$ Unsure of myself \\
& $\checkmark$ Submissive & $\checkmark$ Indecisive \\
& $\checkmark$ Unable to plan & $\checkmark$ Passive \\
& $\checkmark$ Easily-influenced & $\checkmark$ Conformist \\
Femininity & &
\end{tabular} Profile 2
$\checkmark$ Skilled in leading
High scores on:
$\checkmark$ Unsure of myself
$\checkmark$ Passive
Conformist

Attitude

toward

teaching

science

Attitude

toward

teaching mathematics

Self-efficacy for

teaching

science

Self-efficacy for

teaching

mathematics
Low scores on:

$\checkmark \quad$ I have enough content mastery to support my students in designing and conducting scientific investigation.

High scores on:

$\checkmark$ I feel nervous teaching science.

$\checkmark \quad$ I think that most primary teachers find science a difficult subject in terms of $\checkmark$ I feel happy while teaching science. content.

Low scores on: High scores on:

$\checkmark$ Teaching math makes me happy. $\quad \checkmark \quad$ I think that teaching math is essential

$\checkmark$ I have enough content knowledge in for child development in primary school. math to adequately teach this subject in $\checkmark$ I think that math should be taught in primary school.

High scores on:

$\checkmark$ Teaching math makes me nervous.

Low scores on:

$\checkmark$ I know how to teach scientific concepts effectively.

$\checkmark$ I understand scientific concepts well enough to be effective at teaching science.

High scores on:

$\checkmark$ I like children

$\checkmark$ Understanding

$\checkmark$ Generous

$\checkmark$ Cooperative

High scores on:

$\checkmark$ I think that science should be taught in primary school as soon as possible.

$\checkmark$ Teaching science is so important in primary school that non-expert teachers should receive additional information in this area.

primary school as soon as possible.

$\checkmark$ If primary students are not able to

find a solution during math tasks, I think

I could be successful at helping them solve the problem.

High scores on:

$\checkmark$ When I teach science, I will answer students' questions.

to teach science.

$\checkmark$ A students' insufficient preparation in

$\checkmark$ The teacher is usually responsible for science can be overcome with good

their students' achievement in science. teaching.

Low scores on:

$\checkmark$ I know how to teach mathematical $\quad \checkmark$ A students' insufficient preparation in concepts effectively.

$\checkmark$ The teacher is usually responsible for teaching.

their students' achievement in math $\quad \checkmark$ I will continually look for better ways

$\checkmark$ I understand mathematical concepts to teach math.

well enough to be effective at teaching $\quad \checkmark$ When I teach math, I will answer math. students' questions. attitudes and the self-efficacy related to teaching science and mathematics have averages that are superior to the mean of the scale that was used to measure these variables. Even if this might sound encouraging, it is crucial to conduct a deeper analysis that takes into account the dispersion of each variable. In other words, when the observed average is used with comparative purposes, it was found that an important group of preservice primary teachers had attitudes and self-efficacy levels that were lower than average ( $9 \%$ approximately) or much lower than average (between $18 \%$ and $22 \%$, approximately).

This result is worrying because low self-efficacy and less-favorable attitudes toward science and mathematics, as seen reported in the literature, translate into teachers who use lecture-style lessons and have a more theoretical approach (Mateos-Núñez et al., 2020; Ren et al., 2016), avoid exploration or inquiry activities (Menon \& Sadler, 2016), are more dependent on teaching resources such as textbooks (Menon \& Sadler, 2016), and 
dedicate less time to teaching science (Korur et al., 2016) and mathematics (Legañoa et al., 2017).

This ensemble of pedagogical practices can negatively impact students' creativity, (Chan \& Lay, 2021), their learning of these disciplines (Menon \& Sadler, 2016; Nelson, 2015) and their interest toward pursuing a STEM career (Wendt \& Rockinson-Szapkiw, 2018; Wilkins, 2010). Another disturbing aspect is that less-favorable attitudes toward science and mathematics and low perceptions of self-efficacy in the teaching of these disciplines, are mainly transferred to girls, possibly because elementary teachers are mainly women (Ren et al., 2016).

According to personality traits associated with gender, it was found that on the subscales representing positive traits, either typically feminine (femininity subscale) or typically masculine (masculinity subscale), the averages are above the median of the instrument scale. Likewise, the subscales that represent negative traits, typically feminine (submission subscale) and typically masculine (machismo subscale), showed averages that were below the median of the scale.

Even if these results might be auspicious, when the variability of each subscale is observed, taking as reference the group average, it can be noted that there is an important percentage of female participants that displayed levels of femininity and masculinity that are below the average (11\% and $14 \%$, respectively) or much lower than the average ( $21 \%$ and $23 \%$, respectively), and levels of submission and machismo that are higher than average (7\% and $8 \%$, respectively) or much higher than the average $(21 \%$ and $13 \%$, respectively).

From these four subscales, masculinity and submission have traits that can be related to the work that is performed in science and mathematics (Szabó et al., 2020). In this way, female participants with low levels of masculinity reported low presence of traits such as being analytical, reflective, and also low presence of characteristics related to higher self-efficacy, like being self-assured and confident. Likewise, a number of female participants reported important levels of submission, traits that might not be aligned with what is usually required in science and mathematics, such as being incapable of making plans, conformist, passive, indecisive, dependent, and unsure of themselves, among others.

These characteristics or beliefs about gender reported by female pre-service teachers is worrying, because they are transmitted implicitly to students (Bassi et al., 2016), through pedagogical resources, teaching methods, and classroom interactions (UNESCO, 2019). In fact, the classroom climate is not free of prejudices and genderbased stereotypes can be conveyed implicitly or subconsciously to students through interactions between teachers and students (Bassi et al., 2016). These teaching practices could help to explain the gender gaps in mathematics (Espinoza \& Taut, 2016) and science courses (Camacho, 2018).

In addition, the more consolidated these gender beliefs are, the more they are instilled in students (Keller, 2007), affecting their self-esteem and self-efficacy (Arias, 2016; Legañoa et al., 2017). Again, this effect would be higher in female students (Beilock et al., 2010; Ren et al., 2016) because their teachers, mainly women, are the first representatives of the scientific community with whom they will have contact (Michaluk et al., 2018). For female students, perceiving these beliefs in their teachers can lead them to see incompatibilities between their gender and STEM areas; this could lead to high insecurity, a low sense of identity with, and less motivation towards STEM from these students (London et al., 2011).

Regarding the research question: what is the relationship between attitudes and self-efficacy toward teaching science and mathematics and gender stereotypes of pre-service primary teachers?, correlations of different magnitudes were found between the variables of the study: the correlations were high between self-efficacy and attitudes (related to teaching science and mathematics), both are socioaffective variables and are hence related (Bursal, 2010; Korur et al., 2016; Menon \& Sadler, 2016), especially when the subject area is the same. This is consistent with other studies that have also found a positive relationship between attitudes and self-efficacy related to teaching science (Türer \& Kunt, 2015; Ultay et al., 2020) and mathematics (Cakiroglu \& Isiksal, 2009).

This indicates that pre-service primary teachers who have favorable attitudes towards teaching science and mathematics also have higher levels of self-efficacy for teaching these subjects, and vice-versa. This relationship is of utmost importance, as several studies have shown (Cakiroglu \& Isiksal, 2009; Haser, 2006; Shulman, 1986), given that an effective teacher should have favorable attitudes and beliefs about teaching to have a positive effect on their students' learning. On the contrary, if a primary teacher has unfavorable attitudes toward teaching science and mathematics and low levels of selfefficacy towards teaching these subjects, this could have a negative effect on the pedagogical practice of the teacher and on the attitudes of their students towards these content areas.

Another relevant correlation for STEM areas was observed between the subscales of submission and masculinity, which was negative and statistically significant. This indicates that participants who identified with negative feminine traits, like dependence, subordination, and weakness, generally tended to have fewer traits considered masculine and positive, like pragmatism and action-orientedness (Lara, 1993), and vice versa.

A high level of submission corresponds to cultural expectations for women in traditional societies like 
Chile; whereas if they present traits typically associated with masculinity, then they are judged as aggressive by their school communities or by society in general (Ezzati, 2009). However, people and women who identify with STEM areas, normally have traits that are culturally more associated with masculinity and may distance themselves from traits that are found on the submission subscale (Szabó et al., 2020). Furthermore, women who work in STEM fields recognize that the atmosphere is hostile, they feel isolated and intimidated by their male peers, and have less self-confidence (London et al., 2011). In this sense, teachers with high levels of submission would not tend to be good models for girls who want to be successful in those environments.

Finally, regarding the question: What profiles can be established combining the gender stereotypes, attitudes and self-efficacy toward teaching science and mathematics in pre-service primary teachers? three profiles of pre-service teachers were found.

The first profile is characterized by high masculinity, low submission, and average attitudes and self-efficacy toward teaching science and mathematics. Primary teachers with high masculinity and low submission could be good models for girls, given that these teachers would have positive traits traditionally associated with men, which, as previously explained, could be favorable traits for working in scientific fields (Szabó et al., 2020).

The second profile is characterized by participants with low levels of masculinity and high levels of submission, and low attitudes and self-efficacy related to teaching science and mathematics. Clearly this is the least beneficial and most worrisome profile if these preservice teachers are expected to be role models for girls to imitate and for girls, so that from a young age, they will have a positive disposition toward science and mathematics, so they feel capable of learning these subjects, and so that perhaps they can envision themselves in a STEM career in the future (Beilock et al., 2010; Korur et al., 2016; Menon \& Sadler, 2016; Nelson, 2015).

Finally, the third profile shows a high level of femininity and high attitudes and self-efficacy for teaching science and mathematics. Femininity, which contains characteristics considered feminine and positive, also corresponds to what is socially expected of women in cultures like Chile; that is to say, they have high levels of sensitivity, kindness, politeness, and understanding (Ezzati, 2009). On the other hand, high levels of attitudes and self-efficacy towards teaching science and mathematics would have an impact on their students' learning, on their predisposition towards these subjects, and on their interest in pursuing a STEM career (Kazempour, 2014; Menon \& Sadler, 2016; Wendt \& Rockinson-Szapkiw, 2018; Wilkins, 2010). In this sense, this third profile, which favorably combines traits that are traditionally considered feminine with favorable attitudes towards science and mathematics, could be an interesting profile for encouraging more girls to enter STEM areas.

In conclusion, the gender-related personality traits, attitudes, and self-efficacy toward teaching science and mathematics are generally positive in these pre-service primary teachers. However, there is a substantial percentage of them that have more negative characteristics than the group average. Similarly, these variables are related to each other, forming different configurations or profiles of pre-service primary teachers that will be teaching science and mathematics. The characteristics found here and the profiles of these pre-service teachers could have different types of impact when they start teaching in the field. First, these traits and profiles could affect their pedagogical practices, for example in their classroom interactions, offering more enriching opportunities to boys than girls. Second, their influence could be positive or negative in aspects such as creativity, perception of self-efficacy in science and mathematics classes, predisposition toward learning these subjects, and in the learning of their future students. Finally, as mostly female pre-service teachers, this impact could be greater in girls, promoting or distancing them from STEM areas from their early school years, widening or closing the gender gap.

\section{Limitations}

Regarding the limitations of the study, it is important to mention the heterogeneity of participants; in fact, the sample belongs to just one university and for future studies, it is recommended to broaden the quantity and type of participating institutions dedicated to teacher preparation and to have a more representative sample considering the distribution of men and women that study primary education in Chile. Regarding the instruments that were adapted for this study, it is suggested for future research to estimate reliability and conduct validation procedures

\section{Recommendations and Projections}

Considering recommendations based on these findings, it is essential to examine attitudes and selfefficacy for teaching science and mathematics and gender stereotypes early in primary teacher education programs.

Regarding the attitudes and self-efficacy, pre-service primary teachers need learning experiences that would improve these variables related to how they feel about teaching these subjects, and in this way approach the teaching of science and mathematics with better disposition and more self-confidence (Mateos-Núñez et al., 2020). In this sense, it is fundamental to consider these socio-affective factors and unveil them, for example, using life-narratives related to science and mathematics (Eugenio-Gozalbo et al., 2019; Stoehr \& 
Carter, 2012), given that low perceptions of self-efficacy and low attitudes toward teaching science and mathematics can be attributed to negative experiences during the teacher's own school history (Blalock et al., 2008; Brígido et al., 2013; Dejarnette, 2012; Korur et al., 2016; Mateos-Núñez et al., 2020; Nadelson et al., 2013; Verdugo et al., 2017). This strategy would allow preservice teachers to be more conscious of these factors and it would allow teacher educators to take action toward improving them. For example, Mateos-Núñez et al. (2020), indicate that it is important to adopt more active learning strategies in the teaching methodology courses in these disciplines given that these socio-affective characteristics in pre-service primary teachers are less favorable in theoretical activities and more favorable in practical activities.

With respect to gender stereotypes, it is also important to create more consciousness; to this effect, these biases should be actively discussed in teacher education programs (Mizala et al., 2015). Genderconscious pedagogical practices should also be encouraged, asking pre-service primary teachers to practice unbiased pedagogical interactions or to design classroom materials for their students that go against these gender stereotypes (González-Pérez et al., 2020).

Similarly, a good way of reducing gender stereotypes is through interventions with female role models that could promote interest in STEM areas for both girls and boys (González-Pérez et al., 2020). These role models could include pre-service primary teachers, if the variables examined in this study were addressed early in teacher education.

Finally, in reference to future projections of the study, different studies could be conducted based on the profiles that were found: for example, science and mathematics experiences of female pre-service primary teachers could be examined, or classroom interactions between female pre-service teachers and their students could be analyzed, based on gender.

Author contributions: All authors have sufficiently contributed to the study, and agreed with the results and conclusions.

Funding: This work is supported by the research grant "Fondo de Apoyo a la Investigación (FAI)", Universidad de los Andes, Chile.

Declaration of interest: No conflict of interest is declared by authors.

\section{REFERENCES}

Agencia de la Calidad de la Educación [Agency for the Quality of Education]. (2018). Resultados educativos 2017 [Educational outcomes 2017]. http://archivos. agenciaeducacion.cl/PPT_Conferencia_ER_2017_ web_3.pdf

Arias, O. (2016). Brecha de género en matemáticas: El sesgo de las pruebas competitivas (evidencia para Chile) [Gender gap in mathematics: Competitive tests bias (evidence for Chile)] [Master thesis, Universidad de
Chile]. https:/ / repositorio.uchile.cl/handle/2250/ 139157

Bandura, A. (1977a). Self-efficacy: Toward a unifying theory of behavioral change. Psychological Review, 84(2), 191-215. https://doi.org/10.1016/0146-6402 (78)90002-4

Bandura, A. (1997b). Self-efficacy: The exercise of control. Freeman.

Bandura, A. (2001). Social cognitive theory: An agentic perspective. Annual Review of Psychology, 52(1), 126. https://doi.org/10.1146/annurev.psych.52.1.1

Banilower, E. R., Smith, P. S., Weiss, I. R., Malzahn, K. A., Campbell, K. M., \& Weis, A. M. (2013). Report of the 2012 national survey of science and mathematics education. Horizon Research, Inc. http:/ / www.hori zon-research.com/2012nssme/wp-content/uplo ads/2013/02/2012-NSSME-Full-Report1.pdf

Banjong, D. (2014). Same performance but different perception: Female stereotypes in mathematics emerge in fifth grade. International Online Journal of Educational Sciences, 6, 258-268. https://doi.org/ 10.15345/iojes.2014.02.001

Bassi, M., Blumberg, R. L., \& Mateo Díaz, M. (2016). Under the "cloak of invisibility": Gender bias in teaching practices and learning outcomes. IDB Working Paper Series, No. IDB-WP-696, InterAmerican Development Bank (IDB). https:/ / doi.org/10.18235/0000446

Battaglia, O. R., Di Paola, B., \& Fazio, C. (2017). A quantitative analysis of educational data through the comparison between hierarchical and nothierarchical clustering. Eurasia Journal of Mathematics, Science and Technology Education, 13(8), 4491-4512. https://doi.org/10.12973/eurasia.2017 $.00943 a$

Beilock, S., Gunderson, E., Ramirez, G., \& Levine, S. (2010). Female teachers' math anxiety affects girls' math achievement. PNAS, 107(5), 1860-1863. https:/ / doi.org/10.1073/pnas.0910967107

Blalock, C. L., Lichtenstein, M. J., Owen, S., Pruski, L., Marshall, C., \& Toepperwein, M. (2008). In pursuit of validity: A comprehensive review of science attitude instruments 1935-2005. International Journal of Science Education, 8(7), 961-77. https://doi.org/ 10.1080/09500690701344578

Brígido, M., Borrachero, A. B., Bermejo. M. L., \& Mellado, V. (2013) Prospective primary teachers' self-efficacy and emotions in science teaching. European Journal of Teacher Education, 36(2), 200-217. https:/ / doi.org/10.1080/02619768.2012.686993

Bursal, M. (2010). Turkish, pre-service elementary teachers' self-efficacy beliefs regarding mathematics and science teaching. International Journal of Science and Mathematics Education, 8(4), 
649-666. https://doi.org/10.1007/s10763-0099179-6

Cakiroglu, E., \& Isiksal, M. (2009). Preservice elementary teachers' attitudes and self-efficacy beliefs toward mathematics. Education and Science, 34(151), 132139. http:/ / citeseerx.ist.psu.edu/viewdoc/down load?doi=10.1.1.842.3213\&rep=rep1\&type=pdf

Camacho, J. (2018). Educación científica no sexista. Aportes desde la investigación en didáctica de las ciencias [Non-sexist science education. Contributions from research in science didactics]. Nomadias, 25, 101-120.

Chan, S. H., \& Lay, Y. F. (2021). Effects of attitude, selfefficacy beliefs, and motivation on behavioural intention in teaching science. Eurasian Journal of Educational Research, 93, 219-262. https://doi.org/ 10.14689 / ejer.2021.93.11

Cohen, J. (1992). A power primer. Psychological Bulletin, 112(1), 155-159. http://doi.org/10.1037/00332909.112.1.155

Cvencek, D., Meltzoff, A. N., \& Greenwald, A. G. (2011) Math-gender stereotypes in elementary school children. Child Development, 82(3), 776-779. https:/ / doi.org/10.1111/j.1467-8624.2010.01529.x

de Kraker-Pauw, E., van Wesel, F., Verwijmeren, T., Denessen, E., \& Krabbendam, L. (2016). Are teacher beliefs gender-related? Learning and Individual Differences, 51, 333-340. https://doi.org/ 10.1016/j.lindif.2016.08.040

Dejarnette, N. (2012). America's children: providing early exposure to STEM (science, technology, engineering and math) initiatives. Education, 133(1), 77-84.

Del Río, M. F., Strasser, K., \& Susperreguy, M. I. (2013). Pre-school children's beliefs about gender differences in academic skills. Sex Roles, 34(3-4), 231-238. https://doi.org/10.1007/s11199-0120195-6

Dunkake, I., \& Schuchart, C. (2015). Stereotypes and teacher characteristics as an explanation for the class-specific disciplinary practices of pre-service teachers. Teaching and Teacher Education, 50, 56-69. https:/ / doi.org/10.1016/j.tate.2015.04.005

Espinoza, A. M., \& Taut, S. (2016). El rol del género en las interacciones pedagógicas de aulas de matemática Chilenas [The role of gender in the pedagogical interactions of Chilean mathematics classrooms]. Psykhe, 25(2), 1-18. https://doi.org/ 10.7764/psykhe.25.2.858

Espinoza, P., Arêas da Luz Fontes, A. B., \& ArmsChavez, C. J. (2014). Attributional gender bias: Teachers' ability and effort explanations for students' math performance. Social Psychology of Education, 17, 105-126. https://doi.org/10.1007/ s11218-013-9226-6
Eugenio-Gozalbo, M., Aragón, L., Vicente, J., \& JiménezTenorio, N. (2019). Análisis de las experiencias de aprendizaje de las ciencias de los/as maestros/as de educación infantil y primaria en formación inicial a través de sus relatos de vida [Analysis of the science learning experiences of early childhood and primary education teachers in initial training through their life stories]. Didáctica de las Ciencias Experimentales y Sociales [Didactics of Experimental and Social Sciences], 37, 107-126. https://doi.org/ 10.7203/DCES.37.14303

Ezzati, G. R. (2009). La imagen social de la femineidad y masculinidad en la enseñanza secundaria en Chile [The social image of femininity and masculinity in secondary education in Chile]. Educar [Educate], 35, 95-106. https:/ / doi.org/10.1590/S0104-4060200900 0300008

Finlayson, M. (2014). Addressing math anxiety in the classroom. Improving Schools, 17(1), 99-115. https:/ / doi.org/10.1177/1365480214521457

Gencer, A. S., \& Cakiroglu, J. (2007). Turkish preservice science teachers' efficacy beliefs regarding science teaching and their beliefs about classroom management. Teaching and Teacher Education, 23(5), 664-675. https:/ / doi.org/10.1016/j.tate.2005.09.013

González-Pérez, S., Mateos de Cabo, R., \& Sáinz, M. (2020). Girls in STEM: Is it a female role-model thing? Frontiers in Psychology, 11, 1-21. https:/ / doi.org/10.3389/fpsyg.2020.02204

Gurin, A., Jeanneret, G. Pearson, M. Pulley, M., Salinas, A., \& Castillo-Garsow, C. (2017). The dynamics of math anxiety as it is transferred through peer and teacher interactions. https://mtbi.asu.edu/sites/ default/files/manuscript_0.pdf

Hair, J., Anderson, R., Tatham, R., \& Black, W. (1999). Análisis multivariante [Multivariate analysis]. Pearson Prentice Hall.

Haney, J., Lumpe, A., Czerniak, C., \& Egan, V. (2002). From beliefs to actions: The beliefs and actions of teachers implementing change. Journal of Science Teacher Education, 13(3), 171-187. https://doi.org/ 10.1023/A:1016565016116

Haser, C. (2006). Investigation of preservice and inservice teachers' mathematics related beliefs in Turkey and the perceived effect of middle school mathematics education program and the school context on these beliefs [Unpublished doctoral dissertation]. Michigan State University.

Hinnant, J. B., O'Brien, M., \& Ghazarian, S. R. (2009). The longitudinal relations of teacher expectations to achievement in the early school years. Journal of Educational Psychology, 101(3), 662-670. https:/ / doi.org/10.1037/a0014306

Jones, M. G., \& Leagon, M. (2014). Science teacher attitudes and beliefs: Reforming practice. In N. G. 
Lederman \& S. K. Abell (Eds.). Handbook of research on science education (Vol. II, pp. 830-847). Taylor and Francis.

Kazempour, M. (2014). I can't teach science! A case study of an elementary preservice teacher's intersection of science experiences, beliefs, attitude, and selfefficacy. International Journal of Environmental $\mathcal{E}$ Science Education, 9(1), 77-96. https://files.eric.ed. gov/fulltext/EJ1016889.pdf

Keller, J. (2007). Stereotype threat in classroom settings: The interactive effect of domain identification, task difficulty and stereotype threat on female students' maths performance. British Journal of Educational Psychology, 77(2), 323-338. https:// doi.org/10.1348 /000709906X113662

Korur, F., Vargas, R. V., \& Serrano, N. T. (2016). Attitude toward science teaching of Spanish and Turkish inservice elementary teachers: Multi-group confirmatory factor analysis. Eurasia Journal of Mathematics, Science and Technology Education, 12(2), 303-320.

https:/ / doi.org/10.12973/eurasia.2016.1215a

Lara, M. A. (1993). Inventario de masculinidad y feminidad [Inventory of masculinity and femininity]. Manual Moderno.

Legañoa, M. A., Báez, M., \& García, J. (2017). Las actitudes hacia la matemática: Preparación de los maestros para considerarlas [Attitudes toward mathematics: Preparing teachers to consider them]. Transformación [Transformation], 13(1), 56-65.

Lewis, R. (2015). Elementary science anxiety: Impact of experience and gender [Honors thesis, Texas State University].

London, B., Rosenthal, L., Levy, S. R., \& Lobel, M. (2011). The influences of perceived identity compatibility and social support on women in nontraditional fields during the college transition. Basic and Applied Social Psychology, 33(4), 304-321. https: / / doi.org/10.1080/01973533.2011.614166

Martínez-Gómez, J. A., Guerrero-Rodríguez, S. I., \& ReyAnacona, C. A. (2012). Evaluación de la validez de constructo y la confiabilidad del inventario de masculinidad y femineidad en adolescentes y adultos jóvenes colombianos [Evaluation of the construct validity and reliability of the inventory of masculinity and femininity in Colombian adolescents and young adults]. Avances en Psicología Latinoamericana [Advances in Latin American Psychology], 30(1), 170-181.

Mateos-Núñez, M., Martínez-Borreguero, G., \& NaranjoCorrea, F. L. (2020). Comparación de las emociones, actitudes y niveles de autoeficacia ante áreas STEM entre diferentes etapas educativas [Comparison of emotions, attitudes and levels of self-efficacy in STEM areas between different educational stages].
European Journal of Education and Psychology, 13(1), 49-64. https:/ / doi.org/10.30552/ejep.v13i1.292

Menon, D., \& Sadler, T. (2016). Preservice elementary teachers' science self-efficacy beliefs and science content knowledge. Journal of Science Teacher Education, 27(6), 649-673. https:/ / doi.org/10.1007/ s10972-016-9479-y

Michaluk, L., Stoiko, R., Stewart, G., \& Stewart, J. (2018). Beliefs and attitudes about science and mathematics in pre-service elementary teachers, STEM, and non-STEM majors in undergraduate physics courses. Journal of Science Education and Technology, 27(2), 99-113. https:/ / doi.org/10.1007/ s10956-017-9711-3

Ministerio de Educación [Ministry of Education]. (2012). Estándares orientadores para egresados de carreras de pedagogía en educación básica [Guiding standards for graduates of pedagogy careers in basic education]. https:/ / www.cpeip.cl/wp-content/uploads / 2019/03/Est\%C3\%A1ndares_B\%C3\%A1sica.pdf

Ministerio de Educación [Ministry of Education]. (2017). Estadísticas de la educación 2016 [Education statistics 2016]. https://centroestudios.mineduc.cl/wpcontent/uploads/sites/100/2017/07/Anuario_20 16.pdf

Mizala, A., Martínez, F., \& Martínez, S. (2015). Preservice elementary school teachers' expectations about student performance: How their beliefs are affected by their mathematics anxiety and student's gender. Teaching and Teacher Education, 50, 70-78. https:/ / doi.org/10.1016/j.tate.2015.04.006

Moscovici, S. (1985). Psicología social I, influencia y cambio de actitudes, individuos y grupos [Social psychology I, influence and change of attitudes, individuals and groups]. Paidós.

Nadelson, L. S., Callahan, J., Pyke, P., Hay, A., Dance, M., \& Pfiester, J. (2013). Teacher STEM perception and preparation: inquiry-based STEM professional development for elementary teachers. The Journal of Educational Research, 106(2), 157-168. https:/ / doi.org/10.1080/00220671.2012.667014

Nelson, L. D. (2015). A case study exploring the ways preservice elementary teachers with low levels of mathematics self-efficacy believe their mathematical ability will affect their teaching effectiveness [Doctoral dissertation, University of Akron].

Oppermann, E., Brunner, M., \& Anders, Y. (2019). The interplay between preschool teachers' science selfefficacy beliefs, their teaching practices, and girls' and boys' early science motivation. Learning and Individual Differences, 70, 86-99. https://doi.org/ 10.1016/j.lindif.2019.01.006

Organisation for Economic Co-operation and Development. (2016). PISA 2015 results (Volume I) 
Excellence and equity in education. https:/ / doi.org/ 10.1787/9789264266490-en

Organización de las Naciones Unidas para la Educación, la Ciencia y la Cultura [United Nations Educational, Scientific and Cultural Organization]. (2016). Informe de resultados del tercer estudio regional comparativo y explicativo (TERCE) [Results report of the third regional comparative and explanatory study]. REICE. Revista Iberoamericana Sobre Calidad, Eficacia Y Cambio En Educación [Ibero-American Journal on Quality, Efficacy, and Change in Education], 14(4). https:/ / doi.org/10.15366/reice2016.14.4.001

Peker, M., Erol, R., \& Gultekin, M. (2018). Investigation of the teacher self-efficacy beliefs of math teachers. Malaysian Online Journal of Educational Sciences, 6(4), 1-11.

https:/ / files.eric.ed.gov/fulltext/EJ1192965.pdf

Ren, L., Green, J., \& Smith, W. (2016). Using the Fennema-Sherman mathematics attitude scales with lower-primary teachers. Mathematics Education Research Journal, 28(2), 303-326. http://doi.org/ 10.1007/s13394-016-0168-0

Reuben, E., Sapienza, P., \& Zingalesc, L. (2014). How stereotypes impair women's careers in science. Proceedings of the National Academy of Sciences of the United States of America, 111(12), 4403-4408. https:// doi.org/10.1073/pnas.1314788111

Riegle-Crumb, C., Morton, K., Moore, C., Chimonidou, A., Labrake, C., \& Kopp, S. (2015). Do inquiring minds have positive attitudes? The science education of preservice elementary teachers. Science Education, 99(5), 819-836. https:// doi.org/10.1002/sce.21177

Saad, R., \& Boujaoude, S. (2012). The relationship between teachers' knowledge and beliefs about science and inquiry and their classroom practices. Eurasia Journal of Mathematics, Science \& Technology Education, 8(2), 113-128. https:/ / doi.org/10.12973/ eurasia.2012.825a

Shepherd, M. A. (2016). Effects of race/ethnicity, gender, and intonation on secondary science teachers' evaluation of spoken responses. Urban Education, 123. https:/ / doi.org/10.1177/0042085916660346

Shulman, L. S. (1986). Those who understand: Knowledge growth in teaching. Educational Researcher, 15(2), 4-14. https://doi.org/10.2307/ 1175860

Spelke, E. (2005). Sex differences in intrinsic aptitude for mathematics and science? American Psychologist, 60(9), 950-958. https://doi.org/10.1037/0003066X.60.9.950

Stern, H. H. (1983). Fundamental concepts of language teaching. Oxford University Press.

Stoehr, K., \& Carter, K. (2012). Positive turning points for girls in mathematics classrooms: Do they stand the test of time? In L. R. Van Zoest, J. J. Lo, \& J. L. Kratky (Eds.). Proceedings of the 34th Annual Meeting of the North American Chapter of the International Group for the Psychology of Mathematics Education (pp. 765768). Western Michigan University.

Szabó, J., Révész, H. G., \& Van-Dyke, D. (2020). The most important attributes for talented students who want to be scientists. Gifted Education International, 37(3), 1-14. https:// doi.org/10.1177/026142942094 7092

Thomas, A. (2017). Gender differences in students' physical science motivation are teachers' implicit cognitions another piece of the puzzle? American Educational Research Journal, 54(1), 1-24. https:// doi.org/10.3102/0002831216682223

Türer, B., \& Kunt, H. (2015). A review of relationship between prospective science teachers' attitudes towards science education and their self-efficacy. Journal of Education and Training Studies, 3(6), 166178. https:// doi.org/10.11114/jets.v3i6.983

Ultay, N., Ultay, E., \& Yilmazer, H. (2020). Determining the relationship between preschool teachers' attitudes towards science teaching and self-efficacy beliefs in terms of various variables. Science Education International, 31(4), 391-399. https://doi.org/10.33828/sei.v31.i4.8

United Nations Educational Scientific and Cultural Organization. (2019). Cracking the code: Girls' and women's education in science, technology, engineering and mathematics (STEM). https://unesdoc.unesco. org/ark:/48223/pf0000253479

van Aalderen-Smeets, S. I., \& van der Molen, J. W. (2013). Measuring primary teachers' attitudes toward teaching science: Development of the dimensions of attitude toward science (DAS) instrument. International Journal of Science Education, 35(4), 577600.

https:/ / doi.org/10.1080/09500693.2012.755576

van Aalderen-Smeets, S. I., van der Molen, J. W., \& Asma, L. J. F. (2012). Primary teachers' attitudes toward science: A new theoretical framework. Science Education, 96(1), 158-182. https://doi.org/ $10.1002 /$ sce. 20467

van der Sandt, S., \& O'Brien, S., (2017). Impact of instructor teaching style and content course on mathematics anxiety of preservice teachers. Journal of Technology Education, 29(1), 95-111. https:// doi.org/10.21061/jte.v29i1.a.5

Varas, L., Felmer, P., Gálvez, G., Lewin, R., Martínez, C., Navarro, S., Ortiz, A., \& Schwarze, G. (2018). Oportunidades de preparación para enseñar matemáticas de futuros profesores de educación general básica en Chile. Calidad en la Educación [Quality in Education], 29, 64-88. https:// doi.org/10.31619/caledu.n29.188 
Verdugo, M., Asún, R., \& Martínez, S. (2017). Validación de la escala de creencias de eficacia en la enseñanza de la matemática (ECEEM) y caracterización de las creencias de estudiantes de pedagogía básica [Validation of the scale of beliefs of effectiveness in the teaching of mathematics (ECEEM) and characterization of the beliefs of students of basic pedagogy]. Calidad en la Educación [Quality in Education], 47, 145-178. https://doi.org/10.4067/ S0718-45652017000200145

Wendt, J., \& Rockinson-Szapkiw, A. (2018). A psychometric evaluation of the English version of the dimensions of attitudes toward science instrument with a U.S. population of elementary educators. Teaching and Teacher Education, 70, 24-33. https:/ / doi.org/10.1016/j.tate.2017.11.009
Wilkins, J. L. M. (2010). Elementary school teachers' attitudes toward different subjects. The Teacher Educator, 45(1), 23-36. https://doi.org/10.1080/ 08878730903386856

Yeigh, T., Woolcott, G., Donnelly, J., Whannell, R., Snow, M., \& Scott, A. (2016). Emotional literacy and pedagogical confidence in pre-service science and mathematics teachers. Australian Journal of Teacher Education, 41(6), Article 7. https://doi.org/ $10.14221 /$ ajte.2016v41n6.7

Zhu, B., \& Zhou, Y. (2012). A study on students' affective factors in junior high school English teaching. English Language Teaching, 5(7), 33-41. https:/ / doi.org/10.5539/elt.v5n7p33

\section{http://www.ejmste.com}

